\title{
Penerimaan Pegawai Terhadap SIMTEG Bintang Pelajar dengan Technology Acceptance Model
}

\author{
Sari Hartini ${ }^{\# 1}$, Titik Misriati ${ }^{* 2}$, Widiarina ${ }^{* 3}$, Rifda Nadhifah ${ }^{\# 4}$ \\ ${ }^{\text {\#} P r o g r a m ~ S t u d i ~ T e k n i k ~ I n f o r m a t i k a, ~ S T M I K ~ N u s a ~ M a n d i r i ~ J a k a r t a ~}$ \\ Jl. Damai No. 8 Warung Jati Barat (Margasatwa) Jakarta Selatan \\ ${ }^{1}$ sari.shi@nusamandiri.ac.id \\ ${ }^{4}$ rifda@gmail.com \\ *Fakultas Teknologi Informasi, Universitas Bina Sarana Informatika \\ Jl. Kamal Raya No.18, Ringroad Barat, Cengkareng, Jakarta Barat \\ ${ }^{2}$ titik.tmi@bsi.ac.id \\ ${ }^{3}$ widiarina.wda@bsi.ac.id
}

\begin{abstract}
Abstrak- SIMTEG (Sistem Informasi Manajemen Terintegrasi) yang dikembangkan oleh Bimbel Bintang Pelajar diharapkan dapat meningkatkan kinerja bagi pegawai. Sejauh ini, masih terdapat beberapa kendala yang dihadapi pegawai sebagai user dalam penggunaan SIMTEG. Oleh karena itu, untuk mengetahui penerimaan pegawai terhadap keberhasilan pengimplementasian SIMTEG, maka perlu dilakukan evaluasi dengan menggunakan metode Technology Acceptance Model. Data yang didapat dari 30 responden dengan skala likert, diperoleh hasil yang menunjukkan terdapat pengaruh signifikan antara kemudahan penggunaan dan kemanfaatan terhadap penerimaan SIMTEG Bintang Pelajar. Dengan nilai korelasi sebesar 0,779 hasil penelitian menunjukkan bahwa kemudahan penggunaan dan kemanfaatan berpengaruh $59,3 \%$ kepada penerimaan pegawai terhadap SIMTEG.
\end{abstract}

\section{Kata kunci - Sistem Informasi, Bintang Pelajar, Technology} Acceptance Model

\section{Pendahuluan}

Teknologi sistem informasi yang mulai berkembang menjadi suatu hal yang menarik untuk diterapkan, terutama dalam memudahkan berjalannya kegiatan operasional di suatu perusahaan, khususnya perusahaan jasa bimbingan belajar. SIMTEG adalah akronim dari Sistem Informasi Manajemen Terintegrasi, sebuah sistem yang dikembangkan oleh Bimbel Bintang Pelajar yang diharapkan dapat meningkatkan produktifitas kerja pegawai, memudahkan dalam perihal pendaftaran, pembayaran, pembuatan laporan, pengisian kehadiran siswa, laporan perkembangan siswa dan lain-lain, sehingga seluruh pekerjaan dapat dilakukan dengan cepat, tepat dan akurat yang berdampak untuk memaksimalkan pelayanan kepada pelanggan. Sebelumnya, Bintang Pelajar menggunakan sistem terpadu tersendiri yang diperuntukan hanya untuk pencetakan kwitansi pembayaran, sementara untuk guru masih menggunakan alat tulis manual dan Microsoft excel/google spreadsheet untuk membuat laporan perkembangan siswa.

Dengan diimplementasikan dan dikembangkan SIMTEG sebagai media yang diharapkan dapat membantu pekerjaan pegawai, perlu adanya pengukuran sejauh mana SIMTEG dapat diterima dan memudahkan pekerjaan pegawai. Salah satu metode yang digunakan untuk mengetahui bahwa sebuah teknologi dapat diterima adalah metode Technology Acceptance Model (TAM), suatu model penerimaan sistem teknologi informasi yang akan digunakan oleh pemakai [1]

Berdasarkan uraian tersebut, penulis melakukan penelitian untuk menganalisa penerimaan pegawai terhadap SIMTEG bintang pelajar dengan metode Technology Acceptance Model.

Permasalahan yang ada dapat diidentifikasikan sebagai berikut:

1. Seberapa besar persepsi penerimaan pegawai terhadap kemudahan dan kemanfaatan SIMTEG Bintang Pelajar

2. Faktor-faktor apa saja yang mempengaruhi penerimaan implementasi SIMTEG Bintang Pelajar Summarecon Bekasi bila ditinjau dengan menggunakan Technology Acceptance Model (TAM)

Sesuai dengan permasalahan yang telah diidentifikasi sebelumnya, penulis memiliki maksud sebagai berikut:

1. Mengetahui implementasi SIMTEG Bintang Pelajar memberi kemudahan dan bermanfaat bagi pegawai.

2. Menganalisa faktor-faktor yang dapat mempengaruhi penerimaan SIMTEG Bintang Pelajar. 


\section{TINJAUAN PUSTAKA}

\section{A. Sistem Informasi Manajemen}

Sistem merupakan suatu kumpulan dari komponenkomponen yang membentuk satu kesatuan [2]. Sebuah organisasi dan sistem informasi adalah sistem fisik dan sosial yang ditata sedemikian rupa untuk mencapai tujuan tertentu.

Informasi merupakan data yang telah diolah menjadi bentuk yang lebih berguna dan berarti bagi pemakai informasi [3]. Informasi adalah segala suatu keterangan yang bermanfaat bagi para pengambil keputusan dalam rangka mencapai tujuan organisasi yang telah ditetapkan [4].

Sistem informasi manajemen adalah sebuah sistem yang selain melakukan pengolahan transaksi yang sangat berguna untuk kepentingan organisasi, juga banyak memberikan dukungan informasi dan pengolahan untuk fungsi manajemen dalam pengambilan keputusan.

\section{B. Technology Acceptance Model (TAM)}

Salah satu teori tentang penggunaan sistem teknologi informasi yang dianggap sangat berpengaruh dan umumnya digunakan untuk menjelaskan penerimaan individual terhadap penggunaan sistem teknologi informasi adalah model penerimaan teknologi (Technology Acceptance Model). Teori ini pertama kali dikenalkan oleh Davis(1986).

Model penerimaan Technology Acceptance Model merupakan suatu model penerimaan sistem teknologi informasi yang akan digunakan oleh pemakai [5].

Technology acceptance model (TAM) yang pertama yang belum dimodifikasi menggunakan lima konstruk utama. Kelima konstruk ini adalah [5]:

1. Kegunaan persepsian (perceived usefulness)

Merupakan sejauh mana seseorang percaya bahwa penggunaan suatu teknologi dapat meningkatkan kinerja pekerjaannya.

2. Kemudahan penggunaan (perceived ease of use) Adalah sejauh mana seseorang percaya bahwa menggunakan suatu teknologi akan bebas dari usaha.

3. Sikap terhadap perilaku (attitude towards behaviour) atau sikap menggunakan teknologi (attitude towards using technology)

Didefinisikan oleh Davis et al. (1989) sebagai perasaanperasaan positip atau negatip dari seseorang jika harus melakukan perilaku yang akan ditentukan.

4. Niat perilaku (behavioral intention) atau niat perilaku menggunakan teknologi (behavioral intention to use) Adalah suatu keinginan (niat) seseorang untuk melakukan suatu perilaku yang tertentu.

5. Perilaku (behavior) atau penggunaan teknologi sesungguhnya.

Dalam konteks sistem teknologi informasi adalah penggunaan sesungguhnya (actual use) dari teknologi.

Kelebihan-kelebihan TAM , sebagai berikut:
1. TAM merupakan model perilaku (behavior) yang bermanfaat untuk menjawab pertanyaan mengapa banyak sistem teknologi informasi gagal diterapkan karena pemakainya tidak mempunyai niat (intention) untuk menggunakannya. Tidak banyak model-model penerapan sistem teknologi informasi yang memasukkan faktor psikologis atau perilaku (behavior) di dalam modelnya dan TAM adalah salah satu yang mempertimbangkannya.

2. TAM dibangun dengan dasar teori yang kuat

3. TAM telah diuji dengan banyak penelitian dan hasilnya sebagian besar mendukung dan menyimpulkan bahwa TAM merupakan model yang baik. Bahkan TAM telah banyak diuji dibandingkan dengan model yang lainnya misalnya Theory Reasoned Action (TRA) dan Theory Planned Behavior (TPB) dan hasilnya juga konsisten bahwa TAM cukup baik.

4. Kelebihan TAM yang paling penting adalah model ini merupakan model yang parsimoni (parsimonious) yaitu model yang sederhana tetapi valid. Membuat model yang sederhana tetapi valid merupakan hal yang tidak mudah. Terjadi trade-off dari pembuatan model. Jika diinginkan model yang sederhana mestinya menggunakan banyak asumsi bahwa faktor-faktor lain tetap berpengaruh pada modelnya, tetapi ini akan berpengaruh pada kualitas dan validitas modelnya yang akan menurun. Sebaliknya jika diinginkan model yang valid dan lengkap, maka semua faktor-faktor pengaruh harus dimasukkan ke dalam model dengan akibat model akan menjadi komplek.

\section{METODOLOGI}

\section{A. Instrumen Penelitian}

Instrumen penelitian adalah suatu alat yang digunakan mengukur fenomena alam maupun sosial yang diamati [6]. Instrumen penelitian yang akan digunakan dalam penelitian ini disusun berdasarkan item-item kuesioner yang sudah digunakan pada penelitian-penelitian sebelumnya. Karena konstruk-konstruk dalam penelitian ini merupakan konstrukkonstruk dari teori TAM yang sudah lama dikembangkan.

TABEL I

INDIKATOR-INDIKATOR KONSTRUK PENELITIAN

\begin{tabular}{|c|c|l|}
\hline Konstruk TAM & \multicolumn{1}{|c|}{ Indikator } & \multicolumn{1}{c|}{ Pernyataan } \\
\hline \multirow{2}{*}{ PEOU } & 1. Mudah dipelajari & $\begin{array}{l}\text { Belajar mengoperasikan } \\
\text { SIMTEG melalui tutorial } \\
\text { yang tersedia mudah } \\
\text { bagi saya }\end{array}$ \\
\cline { 2 - 3 } & $\begin{array}{l}\text { 2. Jelas dan mudah } \\
\text { dipahami }\end{array}$ & $\begin{array}{l}\text { Saya tidak melakukan } \\
\text { kesalahan berkelanjutan } \\
\text { ketika menggunakan } \\
\text { SIMTEG }\end{array}$ \\
\cline { 2 - 4 } & 3. Fleksibel menjadi & $\begin{array}{l}\text { Saya dapat dengan mudah } \\
\text { mengakses SIMTEG kapan } \\
\text { saja dan dimana saja }\end{array}$ \\
\cline { 2 - 3 } & $\begin{array}{l}\text { Mudah bagi saya untuk } \\
\text { menjadi mahir bila } \\
\text { menggunakan SIMTEG } \\
\text { mahir }\end{array}$ \\
\hline
\end{tabular}




\begin{tabular}{|c|c|c|}
\hline \multirow[t]{4}{*}{ PU } & $\begin{array}{l}\text { 1. } \begin{array}{l}\text { Mempercepat } \\
\text { pekerjaan }\end{array} \\
\text {. }\end{array}$ & $\begin{array}{l}\text { Penggunaan SIMTEG } \\
\text { mempercepat pekerjaan } \\
\text { Saya }\end{array}$ \\
\hline & $\begin{array}{ll}\text { 2. } & \text { Meningkatkan } \\
\text { kinerja }\end{array}$ & $\begin{array}{l}\text { Penggunaan SIMTEG } \\
\text { meningkatkan kinerja } \\
\text { pekerjaan Saya }\end{array}$ \\
\hline & 3. Efektifitas & $\begin{array}{l}\text { Penggunaan SIMTEG } \\
\text { meningkatkan efektifitas } \\
\text { pekerjaan Saya }\end{array}$ \\
\hline & $\begin{array}{l}\text { 4. } \begin{array}{l}\text { Mempermudah } \\
\text { pekerjaan }\end{array} \\
\text { a }\end{array}$ & $\begin{array}{l}\text { SIMTEG memudahkan } \\
\text { pekerjaan Saya }\end{array}$ \\
\hline \multirow[t]{4}{*}{ Acceptance of IT } & $\begin{array}{ll}\text { 1. } & \text { Selalu } \\
& \text { menggunakan }\end{array}$ & $\begin{array}{l}\text { Belajar mengoperasikan } \\
\text { SIMTEG melalui tutorial } \\
\text { yang tersedia mudah } \\
\text { bagi saya }\end{array}$ \\
\hline & $\begin{array}{ll}\text { 2. } & \text { Selalu } \\
& \text { mengakses }\end{array}$ & $\begin{array}{l}\text { Saya tidak melakukan } \\
\text { kesalahan berkelanjutan } \\
\text { ketika menggunakan } \\
\text { SIMTEG }\end{array}$ \\
\hline & $\begin{array}{ll}\text { 3. } & \begin{array}{l}\text { Kepuasan } \\
\text { menggunakan }\end{array}\end{array}$ & $\begin{array}{l}\text { Saya dapat dengan mudah } \\
\text { mengakses SIMTEG kapan } \\
\text { saja dan dimana saja }\end{array}$ \\
\hline & $\begin{array}{ll}\text { 4. } & \text { Memberikan } \\
\text { masukan untuk } \\
\text { menggunakan }\end{array}$ & $\begin{array}{l}\text { Mudah bagi saya untuk } \\
\text { menjadi mahir bila } \\
\text { menggunakan SIMTEG }\end{array}$ \\
\hline
\end{tabular}

\section{B. Metode Pengumpulan Data, Populasi dan Sampel}

Pada penelitian ini, pengumpulan data dilakukan dengan menyebar kuesioner kepada responden. Kuesioner dibuat dengan aplikasi google form sehingga memudahkan penyebaran dengan menyebar link melalui pesan whatsapp dan efisien bagi responden untuk mengisi kuesioner. Data dapat langsung terkumpul setelah kuesioner disebar, sehingga tidak membutuhkan waktu yang lama. Penyebaran kuesioner dimulai pada tanggal 10 Juli 2017 sampai tanggal 15 Juli 2017. Data yang didapat berupa tanggapan dari responden secara otomatis direkap di Google Spreadsheet. Data yang didapat kemudian diolah menggunakan aplikasi SPSS 22.

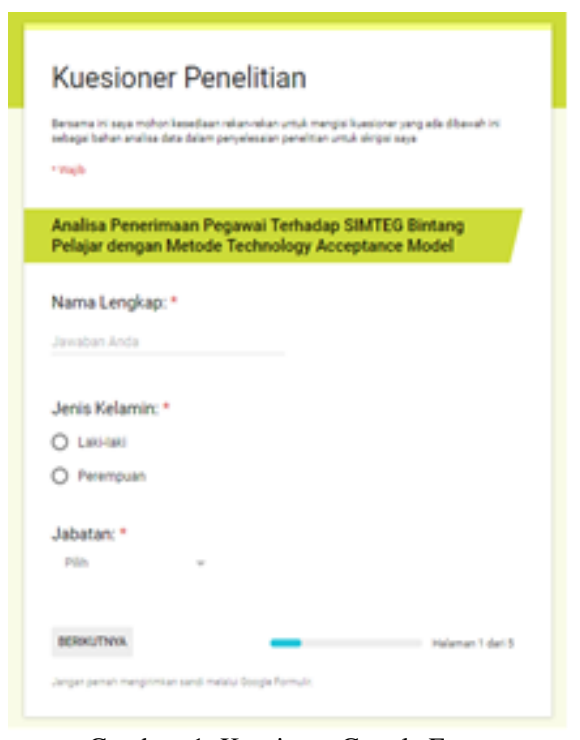

Gambar. 1 Kuesioner Google Form
Jumlah responden yang dijadikan sampel sebanyak 30 orang dari total populasi staff dan guru di Bintang Pelajar Summarecon Bekasi pada bulan Juli 2017 sebanyak 32 orang. Secara tidak langsung, penelitian melibatkan seluruh staff dan guru. Sampel diambil berdasarkan rumus Isaac dan Michael dengan taraf kesalahan 5\%, berikut perhitungannya:

$S=\frac{\lambda^{2} \cdot N \cdot P \cdot Q}{d^{2}(N-1)+\lambda^{2} \cdot P \cdot Q}$

$S=\frac{3,841,32,0,5,0,5}{0,05^{2}(32-1)+3,841,0,5,0,5}=\frac{30,728}{1,03775}=29,61$

$s=29,61$ (dibulatkan menjadi 30)

\section{Keterangan:}

$\mathrm{S}$ = Jumlah sampel

$\lambda 2=$ Derajat Kebebasan 1 dan kesalahan 5\% harga Chi Kuadrat $=3,841$.

$\mathrm{N}=$ Jumlah populasi

$\mathrm{P} \quad=$ Peluang benar $(0,5)$

$\mathrm{Q}=$ Peluang salah $(0,5)$

$\mathrm{D}=$ Perbedaan antara rata-rata sampel dengan rata-rata populasi $(0,05)$

\section{HASIL DAN PEMBAHASAN}

Data demografi responden pada penelitian ini, diklarifikasikan berdasarkan jabatan dan jenis kelamin. Berdasarkan data pada tabel tersebut, seluruh responden berkontribusi $100 \%$ terhadap penelitian ini.

TABEL II

PROFIL RESPONDEN PENELITIAN

\begin{tabular}{|c|c|c|}
\hline Jabatan & Jumlah & Persentase \\
\hline Guru Eksak SD & 2 & $6.67 \%$ \\
\hline Guru Matematika & 6 & $20 \%$ \\
\hline Guru IPA & 2 & $6.67 \%$ \\
\hline Guru IPS & 1 & $3.33 \%$ \\
\hline Guru Fisika & 3 & $10 \%$ \\
\hline Guru Kimia & 4 & $13.33 \%$ \\
\hline Guru Biologi & 2 & $6.67 \%$ \\
\hline Guru Ekonomi & 2 & $6.67 \%$ \\
\hline Guru Bahasa Indonesia & 4 & $13.33 \%$ \\
\hline Guru Bahasa Inggris & 1 & $3.33 \%$ \\
\hline Staff & 3 & $10 \%$ \\
\hline Total & 30 & $100 \%$ \\
\hline Jenis Kelamin & Jumlah & Persentase \\
\hline Laki-laki & 6 & $20 \%$ \\
\hline Perempuan & 24 & $80 \%$ \\
\hline Total & 30 & $100 \%$ \\
\hline
\end{tabular}

Responden pada penelitian ini terdiri dari 27 guru-guru dan 3 staf Bintang Pelajar dengan jenis kelamin 6 laki-laki dan 24 perempuan. 
TABEL III

HASIL UJi VALIDITAS

\begin{tabular}{|c|c|c|c|c|}
\hline No & Indikator Pernyataan & r hitung & $r$ tabel & Hasil \\
\hline 1 & $\begin{array}{l}\text { Belajar mengoperasikan } \\
\text { SIMTEG melalui tutorial } \\
\text { yang tersedia mudah bagi } \\
\text { Saya }\end{array}$ & 0,559 & 0,361 & Valid \\
\hline 2 & $\begin{array}{lr}\text { Saya tidak melakukan } \\
\text { kesalahan } & \text { berkelanjutan } \\
\text { ketika } & \text { menggunakan } \\
\text { SIMTEG } & \\
\end{array}$ & 0,397 & 0,361 & Valid \\
\hline 3 & $\begin{array}{l}\text { Saya dapat dengan } \\
\text { mudah mengakses } \\
\text { SIMTEG kapan saja dan } \\
\text { dimana saja }\end{array}$ & 0,555 & 0,361 & Valid \\
\hline 4 & $\begin{array}{l}\text { Mudah bagi Saya untuk } \\
\text { menjadi mahir bila } \\
\text { menggunakan SIMTEG }\end{array}$ & 0,532 & 0,361 & Valid \\
\hline 5 & $\begin{array}{ll}\begin{array}{l}\text { Penggunaan } \\
\text { mempercepat }\end{array} & \text { SIMTEG } \\
\text { Saya } & \\
\end{array}$ & 0,797 & 0,361 & Valid \\
\hline 6 & $\begin{array}{lr}\begin{array}{l}\text { Penggunaan } \\
\text { meningkatkan } \\
\text { pekerjaan Saya }\end{array} & \text { SIMTEG } \\
\end{array}$ & 0,809 & 0,361 & Valid \\
\hline 7 & $\begin{array}{l}\text { Penggunaan } \\
\text { meningkatkan } \\
\text { pekerjaan Saya }\end{array}$ & 0,641 & 0,361 & Valid \\
\hline 8 & $\begin{array}{l}\text { SIMTEG memudahkan } \\
\text { pekerjaan Saya }\end{array}$ & 0,751 & 0,361 & Valid \\
\hline 9 & $\begin{array}{l}\text { Saya selalu menggunakan } \\
\text { SIMTEG }\end{array}$ & 0,757 & 0,361 & Valid \\
\hline 10 & $\begin{array}{ll}\text { Saya selalu mengakses } \\
\text { SIMTEG }\end{array}$ & 0,737 & 0,361 & Valid \\
\hline 11 & $\begin{array}{l}\text { Saya merasa puas } \\
\text { menggunakan SIMTEG }\end{array}$ & 0,794 & 0,361 & Valid \\
\hline 12 & $\begin{array}{lr}\text { Saya } & \text { memberikan } \\
\text { masukan } & \text { untuk evaluasi } \\
\text { SIMTEG } & \\
\end{array}$ & 0,506 & 0,361 & Valid \\
\hline
\end{tabular}

Uji validitas dilakukan untuk mengetahui keakuratan data yang terkumpul. Tiap indikator variabel dalam kuesioner dengan total dibandingkan dengan $\mathrm{r}$ tabel product moment yang didapat pada taraf signifikansi 0,05 dengan uji dua sisi dan $\mathrm{N}=30$. Maka didapatkan $\mathrm{r}$ tabel sebesar 0,361. Kuesioner dikatakan valid apabila $\mathrm{r}$ hitung (Corected Item Total Corelation) $>\mathrm{r}$ tabel dan kuesioner dikatakan tidak valid apabila $\mathrm{r}$ hitung (Corected Item Total Corelation) $<\mathrm{r}$ tabel.

Dari hasil uji validitas tersebut, tiap indikator pernyataan kuesioner harga $r$ hitung lebih besar daripada $r$ tabel yang bernilai 0,361 . Sehingga dapat disimpulkan setiap indikator dalam pernyataan bernilai valid.

TABEL IV

RELIABILITY STATISTICS

\begin{tabular}{|c|c|}
\hline Cronbach's Alpha & N of Items \\
\hline .878 & 12 \\
\hline
\end{tabular}

Dari hasil uji reliabilitas didapatkan ri $=0,878$ dengan teknik cronbach's alpha yang diketahui nilainya adalah 0,6 . Karena 0,878>0,6 maka dapat disimpulkan hasil sudah reliabel.
TABEL V

DESCRIPTIVE STATISTICS

\begin{tabular}{|l|r|r|r|}
\hline & \multicolumn{1}{|c|}{ Mean } & Std. Deviation & \multicolumn{1}{c|}{ N } \\
\hline Variabel Bebas & 27.57 & 3.711 & 30 \\
\hline Variabel Terikat & 12.67 & 2.537 & 30 \\
\hline
\end{tabular}

1. Jumlah responden yang menjadi sampel adalah 30 orang

2. Rata-rata untuk kemudahan penggunaan dan kemanfaatan sebesar 27,57 dengan standar deviasi sebesar 3,711 artinya jika dihubungkan dengan rata-rata untuk kemudahan penggunaan dan kemanfaatan sebesar 27,57 per orang maka kemudahan penggunaan dan kemanfaatan akan berkisar antara $27,57 \pm 3,711$.

3. Rata-rata untuk penerimaan TI sebesar 12,67 dengan standar deviasi sebesar 2,537. Dengan standar deviasi sebesar 2,537 artinya jika dihubungkan dengan rata-rata untuk penerimaan TI sebesar 12,67 per orang, maka penerimaan TI akan berkisar antara 12,67 $\pm 2,537$.

TABEL VI

\section{CORRELATIONS}

\begin{tabular}{|c|c|c|c|}
\hline & & Variabel Bebas & $\begin{array}{l}\text { Variabel } \\
\text { Terikat }\end{array}$ \\
\hline Variabel Bebas & $\begin{array}{l}\text { Pearson } \\
\text { Correlation } \\
\text { Sig. (2-tailed) } \\
\text { N }\end{array}$ & $\begin{array}{l}1 \\
30\end{array}$ & $\begin{array}{l}.779^{* *} \\
.000 \\
30\end{array}$ \\
\hline $\begin{array}{l}\text { Variabel } \\
\text { Terikat }\end{array}$ & $\begin{array}{l}\text { Pearson } \\
\text { Correlation } \\
\text { Sig. (2-tailed) } \\
\mathrm{N}\end{array}$ & $\begin{array}{l}.779^{* *} \\
.000 \\
30\end{array}$ & $\begin{array}{l}1 \\
30\end{array}$ \\
\hline
\end{tabular}

**. Correlation is significant at the 0.01 level (2-tailed).

Dari tabel diatas menunjukkan bahwa koefisien korelasi antara kemudahan penggunaan dan kemanfaatan dengan perimaan TI adalah $\mathrm{r}=0,779$, maka dapat disimpulkan antara kemudahan penggunaan dan kemanfaatan dengan penerimaan terhadap SIMTEG Bintang Pelajar terjadi hubungan yang kuat (positif), karena koefisien mendekati 1 dan berada diangka antara $0,60-0,799$. Arti positif adalah hubungan antara variabel bebas $(\mathrm{X})$ dan variabel terikat $(\mathrm{Y})$ searah. Jadi semakin tinggi kemudahan penggunaan dan kemanfaatan, maka semakin meningkat penerimaan terhadap SIMTEG. Begitu juga sebaliknya, semakin menurun kemudahan penggunaan dan kemanfaatan SIMTEG, maka semakin menurun penerimaannya.

TABEL VII

\begin{tabular}{|c|c|c|c|c|}
\hline Model & $\mathrm{R}$ & R Square & $\begin{array}{c}\text { Adjusted R } \\
\text { Square } \\
\end{array}$ & $\begin{array}{l}\text { Std. Error of } \\
\text { the Estimate }\end{array}$ \\
\hline 1 & $.779^{\mathrm{a}}$ & .607 & .593 & 1.619 \\
\hline
\end{tabular}

a. Predictors: (Constant), Variabelbebas 
Hasil analisis dari tabel tersebut menunjukkan bahwa kontribusi yang disumbangkan kemudahan penggunaan dan kemanfaatan $(\mathrm{X})$ terhadap penerimaan TI $(\mathrm{Y})=60,7 \%$ dengan nilai korelasi sebesar 0,779. Kemudian didapatkan nilai Adjusted R Square sebesar 0,593 yang artinya 59,3\% penerimaan pegawai terhadap SIMTEG bisa dijelaskan dengan faktor kemudahan penggunaan dan kemanfaatan.

\begin{tabular}{|c|c|c|c|c|c|}
\hline \multicolumn{6}{|c|}{$\begin{array}{c}\text { TABEL VIII } \\
\text { ANOVA }^{A}\end{array}$} \\
\hline Model & $\begin{array}{l}\text { Sum of } \\
\text { Squares }\end{array}$ & Df & $\begin{array}{l}\text { Mean } \\
\text { Square }\end{array}$ & $\mathbf{F}$ & Sig. \\
\hline 1 & Regression & 113.247 & 1 & 113.247 & 43.189 \\
\hline & Residual & 73.420 & 28 & 2.622 & \\
\hline & Total & 186.667 & 29 & & \\
\hline
\end{tabular}

a. Dependent Variable: Variabel terikat

b. Predictors: (Constant), Variabel bebas

Dari tabel diatas, dapat dianalisis sebagai berikut:

1. Hipotesis

Ho = Tidak terdapat pengaruh yang signifikan antara kemudahan penggunaan dan kemanfaatan menggunakan teknologi terhadap penerimaan SIMTEG Bintang Pelajar.

Ha = Terdapat pengaruh yang signifikan antara kemudahan penggunaan dan kemanfaatan menggunakan teknologi terhadap penerimaan SIMTEG Bintang Pelajar.

2. Kaidah Pengujian

Berdasarkan perbandingan antara $F_{\text {hitung }}$ dan $F_{\text {tabel }}$

Jika $\mathrm{F}_{\text {hitung }} \leq \mathrm{F}_{\text {tabel }}$, maka Ho diterima

Jika $\mathrm{F}_{\text {hitung }}>\mathrm{F}_{\text {tabel }}$, maka Ho ditolak

Dimana nilai $F_{\text {hitung }}$ dari tabel anova sebesar 43,189 dan nilai $\mathrm{F}_{\text {tabel }}$ dari tabel $\mathrm{F}=4,20$

$\mathrm{F}_{\text {tabel }}$ dari tabel $\mathrm{F}$ diperoleh dengan cara: mencari degree of freedom $\mathrm{df}(\mathrm{n} 1)=\mathrm{k}-1=1, \mathrm{df}(\mathrm{n} 2)=\mathrm{n}-\mathrm{k}=28$

Berdasarkan nilai probabilitas:

Jika probabilitas $(\mathrm{sig})>\alpha$, maka Ho diterima

Jika probabilitas $(\mathrm{sig})<\alpha$, maka Ho ditolak

Dimana dari tabel Anova nilai probabilitas (sig) $=0,00$

dan nilai taraf signifikan $\alpha=0,05$

$F_{\text {hitung }}=43,189>F_{\text {tabel }}=4,20$, maka Ho ditolak.

Kemudian nilai probabilitas $(\mathrm{sig})=0,00<$ nilai taraf signifikan $\alpha=0,05$

Maka Ho ditolak

Maka dapat diambil keputusan bahwa terdapat pengaruh yang signifikan antara kemudahan penggunaan dan kemanfaatan menggunakan teknologi terhadap penerimaan SIMTEG Bintang Pelajar.
TABEL IX

COEFFICIENTS $^{\mathrm{A}}$

\begin{tabular}{|c|c|c|c|c|c|c|}
\hline & \multirow[b]{2}{*}{ Model } & \multicolumn{2}{|c|}{$\begin{array}{c}\text { Unstandardized } \\
\text { Coefficients }\end{array}$} & \multirow{2}{*}{$\begin{array}{c}\begin{array}{c}\text { Standardized } \\
\text { Coefficients }\end{array} \\
\text { Beta }\end{array}$} & \multirow[b]{2}{*}{$\mathrm{t}$} & \multirow[b]{2}{*}{ Sig } \\
\hline & & B & $\begin{array}{l}\text { Std. } \\
\text { Error }\end{array}$ & & & \\
\hline \multirow[t]{2}{*}{1} & (Constant) & -2.013 & 2.253 & & -.893 & .379 \\
\hline & $\begin{array}{l}\text { Variabel } \\
\text { bebas }\end{array}$ & .533 & .081 & .779 & 6.572 & .000 \\
\hline
\end{tabular}

a. Dependent Variable: Variabel terikat

Dari tabel diatas dapat dianalisa sebagai berikut:

1. Model untuk persamaan regresi untuk memperkirakan penerimaan SIMTEG Bintang Pelajar yang dipengaruhi oleh kemudahan penggunaan dan kemanfaatan adalah $\mathrm{Y}$ $=-2,013+0,533 \mathrm{X}$. Dimana $\mathrm{Y}$ adalah penerimaan $\mathrm{TI}$, sedangkan $\mathrm{X}$ adalah kemudahan penggunaan dan kemanfaatan. Angka konstan bernilai -2,013 yang bermakna jika tidak ada kemudahan penggunaan dan kemanfaatan (X) maka nilai penerimaan TI (Y) adalah sebesar -2,013. Sementara nilai koefisien regresi bernilai 0,533 yang berarti setiap penambahan $1 \%$ tingkat kemudahan penggunaan dan kemanfaatan (X), maka penerimaan TI (Y) akan meningkat sebesar 0,533

2. Uji signifikansi (Korelasi Product Moment Pearson)

a. Hipotesis

Ho $=$ Tidak terdapat pengaruh yang signifikan antara kemudahan penggunaan dan kemanfaatan menggunakan teknologi terhadap penerimaan SIMTEG Bintang Pelajar.

$\mathrm{Ha}=$ Terdapat pengaruh yang signifikan antara kemudahan penggunaan dan kemanfaatan menggunakan teknologi terhadap penerimaan SIMTEG Bintang Pelajar.

b. Taraf signifikan $\alpha=5 \%$

c. Kaidah pengujian

Jika, $-\mathrm{t}_{\text {tabel }} \leq \mathrm{t}_{\text {hitung }} \leq \mathrm{t}_{\text {tabel }}$, maka Ho diterima

Jika, $t_{\text {hitung }}>t_{\text {tabel }}$, maka Ho ditolak

d. Menghitung $t_{\text {hitung }}$ dan $t_{\text {tabel }}$

Nilai $t_{\text {hitung }}$

$t_{\text {hitung }}$

$=\frac{r \sqrt{n-2}}{\sqrt{1-(r)^{2}}}=\frac{0,779 \sqrt{30-2}}{\sqrt{1-(0,779)^{2}}}=\frac{4,122}{0,627}=6,572$

Nilai $t_{\text {tabel }}$ dapat dicari dengan menggunakan tabel distribusi $\mathrm{t}$ dengan taraf signifikansi $\alpha=0.05 / 2=$ 0,025 (dua sisi), dan df $=\mathrm{n}-\mathrm{k}(\mathrm{n}=$ jumlah responden dan $\mathrm{k}=$ jumlah variabel)

$\mathrm{t}_{\text {tabel }}=\mathrm{t}_{(\alpha / 2)(\mathrm{n}-2)}=\mathrm{t}_{(0,05 / 2)(30-2)}=\mathrm{t}_{(0,025)(28)}=2,048$

$\mathrm{t}_{\text {hitung }}=6,572>\mathrm{t}_{\text {tabel }}=2,048$

Karena $t_{\text {hitung }}$ lebih besar dari $t_{\text {tabel }}$ maka Ho ditolak, sehingga Ha diterima. 


\section{KESIMPULAN}

Penelitian ini bertujuan untuk mengevaluasi penerimaan SIMTEG bagi pegawai di Bintang Pelajar Summarecon Bekasi dengan menggunakan Technology Acceptance Model. Dari hasil pengolahan data dan analisis data, didapatkan kesimpulan sebagai berikut:

1. Nilai korelasi yang didapatkan berdasarkan hubungan persepsi kemudahan penggunaan dan kemanfaatan(variabel $\mathrm{X}$ ) dengan penerimaan terhadap TI (variabel Y) mendapatkan hasil 0,779. Nilai tersebut menunjukkan hubungan positif searah antara variabel $\mathrm{X}$ dengan variabel Y. Jika kemudahan penggunaan dan kemanfaatan semakin tinggi, maka semakin meningkat pula penerimaan terhadap IT.

2. Berdasarkan analisis uji signifikansi, dengan taraf signifikansi $5 \%$ didapatkan $t_{\text {hitung }}=6,572>t_{\text {tabel }}=2,048$ sehingga Ha diterima. Maka dapat disimpulkan terdapat pengaruh yang signifikan antara kemudahan penggunaan dan kemanfaatan menggunakan teknologi terhadap penerimaan SIMTEG Bintang Pelajar.

\section{REFERENSI}

[1] R. Oktofiyani, Nurmalasari, and W. Anggraeni, "Penerimaan Sistem ELearning Menggunakan Technology Acceptance Model (TAM) Study Kasus Siswa/i Kelas X Di SMU Negeri 92 Jakarta," J. Pilar Nusa Mandiri, vol. 12, no. 1, pp. 46-53, 2016.

[2] J. S. P. Tyoso, Sistem Informasi Manajemen. Yogyakarta: Deepublish, 2016.

[3] J. Hutatean, Konsep Sistem Informasi. Yogyakarta: Deepublish, 2014.

[4] J. L. Gaol, Sistem Informasi Manajemen Pemahaman dan Aplikasi. Jakarta: Grasindo, 2008.

[5] J. H. Mustakini, "Sistem Informasi Keperilakuan," Yogyakarta: Andi, 2007.

[6] Sugiyono, Metode penelitian pendidikan:(pendekatan kuantitatif, kualitatif dan $R \& D$ ). Bandung: Alfabeta, 2008. 